$\xi=-1$

\title{
Total Productive Maintenance (TPM) Implementation Based on Lean Manufacturing Tools in Indonesian Manufacturing Industries
}

\author{
Erry Yulian Triblas Adesta ${ }^{*}$, Herry Agung Prabowo ${ }^{2}$ \\ ${ }^{1}$ Kulliyah of Engineering, International Islamic University Malaysia (IIUM), Jalan Gombak 53100, Kuala Lumpur, Malaysia \\ ${ }^{2} \mathrm{PhD}$ student of Manufacturing and Material Engineering Department, International Islamic University Malaysia (IIUM), \\ Jalan Gombak 53100, Kuala Lumpur, Malaysia and a Lecturer staff of Universitas Mercu Buana Jakarta. \\ *Corresponding author E-mail: eadesta@gmail.com; eadesta@iium.edu.my
}

\begin{abstract}
Only a few companies in Indonesia have implemented Total Productive Maintenance (TPM) and Lean Manufacturing (LM) properly. They also implemented LM separately with TPM. To look beyond their implementation, a research through survey method will be conducted to identify the status of TPM and LM practices. The data recorded through the survey will be calculated and analysed using Structural Equation Modelling (SEM) with Smart-PLS as a programming tool. The expected results were to provide updated barriers and enablers factors in implementing TPM and LM, to produced reliable CFA (measurement) models for TPM, LM and MP and proposing reference model (structural model) of the relationship between TPM, LM, and MP for manufacturing industries in Indonesia.
\end{abstract}

Keywords: TPM; Maintenance; Lean; Manufacturing; SEM

\section{Introduction}

\subsection{Background}

The manufacturing industry sector was very influential in the structural transformation process of Indonesia economics. In 2001, the manufacturing industry sector contributed approximately $30.1 \%$ of the Indonesia's GDP. In the following years, its contribution went down several times and as low as $21.20 \%$ of the total GDP in 2017 (as presented in Table.1).

Table1.Sectorial Contribution in the Indonesia Economics 1990-2017 impeccant.

\begin{tabular}{|c|c|c|c|}
\hline Year & Agricultural & Manufacturing & Others \\
\hline 1990 & 19.4 & 20.7 & 59.9 \\
\hline 2001 & 15.6 & 30.1 & 54.3 \\
\hline 2011 & 13.9 & 21.8 & 64.3 \\
\hline 2014 & 13.7 & 21.2 & 65.1 \\
\hline 2015 & 13.7 & 20.8 & 65.5 \\
\hline 2016 & 13.8 & 20.5 & 65.7 \\
\hline 2017 & 13.8 & 20.2 & 66.0 \\
\hline
\end{tabular}

\section{Source: [1]}

Although it may have seemed to be unsatisfied condition, in the future, the Indonesian Government, through National Long-Term Development Plans (RPJPN) is planning to make Indonesia a new industrial country where its industrial sector become the main source of income with a yearly growth of $8.6 \%$ and contribute to $40 \%$ of the GDP in 2025 [2]. To achieve this ambitious target Indonesian manufacturing companies needs a very comprehensive and total strategy optimizing their performance, Total Productive Maintenance (TPM) as Lean Manufacturing (LM) tool is one of them.
TPM is an innovative approach to maintenance that optimizes equipment effectiveness, eliminates breakdowns, and promotes autonomous maintenance by operators from day to day activities involving total employee [3]. TPM is a maintenance and production program designed mainly to maximize the effectiveness of all tools through participation and motivation of all staff/employee [3] [4] [5] and [6]. The basic practices of TPM are often called the "pillars" or "elements" of TPM. The entire edifice of TPM is built and stands on eight pillars [3] [4].

The first concept of LM was proposed by the Japanese automotive company Toyota during the 1970 s when it was known as Toyota Production System (TPS). The first goal of TPS was to improve productivity and decrease cost by eliminating waste or non-value added activities [7] [8]. TPS growing rapidly in North America since 1984 and formally called as "Lean" by Krafcik and Womack in the era of 1988-1994 [7] [9] [10]. Mishra [8] gives a brief explanation of the various available lean methods/tools and techniques as follows: Cellular Manufacturing, TPM, Just in time, Continuous Improvement, Production Smoothing and Standardization of Work. There are nine barriers play an important role in the successful implementation of LM, namely high rejection rate, high setup time, high lead time, high level of inventory, lack of top management's commitment, lack of employee's involvement and training, low OEE, lack of dedicated suppliers, and lack of infrastructure and ICT [11].

LM implementation contributes significantly to the enhancement of business performance by eliminating waste (7 waste) namely: transportation, over production, defects, inventory, waiting, motion, and over processing [8]. The wastes generation in manufacturing processes have a strong relationship with the performance of machines or equipment. Thus, a strategic maintenance management such as TPM is really needed to guarantee the successful lean production. Fig. 1 shows the relationships between TPM, LM 
and others manufacturing philosophies. It is clearly revealed, that TPM is the corner stone activity for most of the LM strategy and can effectively contribute towards success of LM.

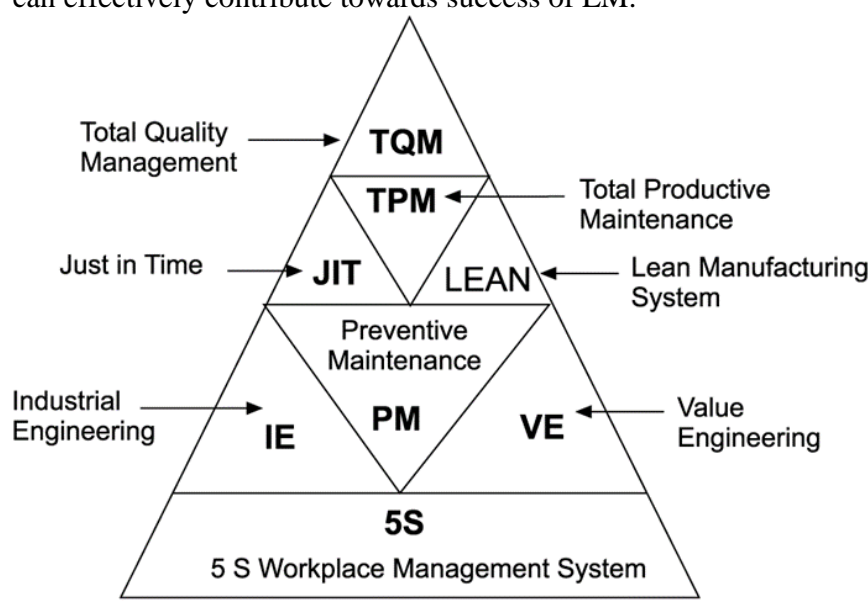

Fig.1.Relationship between TPM, LM and others philosophies [3].

Many companies pursue either TPM or LM to improve their business strategy. However, it is observed that most of the implementation of these initiatives been done separately. The integration of TPM with LM will form a comprehensive and consistent set of manufacturing practices directed towards improved performance. Either TPM or LM initiative has their own strength and has a significant impact to support others. The available literature investigates the relation of TPM and LM quite in a broad a lack of comprehensive research available to integrate the TPM element into LM. A comprehensive integration is suggested to be further studied between these two methodologies rather than just focus on the certain methodology only as per current trend [12]. There is a need for a further research to comprehensively integrate these two initiatives and their impact to MP (manufacturing performance).

\subsection{Research Gap}

To provide a solid foundation for this research, literature studies on 21 major recent journals with the theme of TPM, LM and Manufacturing/ organization Performance has been carried out. So far, extensive research focusing on the integration of TPM and LM and their impact to MP has been very limited, if any. Several researchers have found without having a TPM as complementary, the LM initiative cannot be accomplished [3], [12], [13]. Managing the plant will also be more effective if those initiatives been integrated into one set of manufacturing practice. There is a need for a further research regarding this issue.

In performing the analysis of relationships between TPM and LM, many researchers treated TPM and LM as an observed variable instead of un-observed one. Only limited researchers treated TPM, LM and MP as un-observed variables namely [14], [10], [15], and [13]. In this research, TPM and LM's variables treated as unobserved variables (latent variables) and measured them through their indicators. SEM (Structural Equation Modelling) is the appropriate method to perform the analysis (confirmatory and measurement).

\subsection{Problem Statement}

Businesses need to be able to compete efficiently and quickly respond to market needs and desires of consumers is increasing. There is no doubt that the manufacturing industry is faced with the challenge to seek and implement improvements in their key processes to cope with fluctuations in the market and improve the customer's needs. Applying Total Productive Maintenance (TPM) as Lean Manufacturing (LM) tools is one of the most important concepts that help businesses to compete better.
Only a few companies in Indonesia have implemented TPM and LM properly. Many managers still consider TPM implementation as an additional cost load. So in most cases, maintenance is still reactive in nature. Results from several researches show that many companies within the manufacture industry in Indonesia have a machine/tool performance score below the JIPM world class standard (OEE minimum 85\%). [16] found that OEE value of production line at PT YME is still below the expected standard which is only $77.63 \%$. [17] found that the average effectiveness (OEE) level of Dual Filters DD07 machine during their research was $26.22 \%$. [18] found the OEE value of CTCM machine only $45.24 \%$. [19] found that $41.18 \%$ activities in plastic industries could be categorized as non-value added activities. [20] said from Value Stream Mapping (VSM) analysis in a Golf gloves division discovered $69.38 \%$ activities were non-value added.

It can be said TPM and LM practices in Indonesian manufacturing companies still lagging behind the world class performance. They are still struggling to overcome the implementation's barriers. They also implemented LM separately with TPM. To achieve operational excellence, the models of LM and TPM implementation, and the effect of both on MP is a great importance to be created. By providing current condition of TPM and LM practices, combined with reference model of a relationship between TPM, LM and MP will gives important archive for academic and practitioners (industries).

\subsection{Research Objectives}

From the explanation above, the objectives of this research are

1. To evaluate current practice (barriers and enablers) on TPM and LM.

2. To develop measurement models (CFA models) for TPM, LM and MP.

3. To proposed a model (structural) of the impact of TPM and LM implementation on manufacturing performance (MP).

\section{Materials and Methods}

\subsection{Research Method}

In order to achieve the objectives of this study and to get a good and valid result, a series of research activities was systematically constructed. Those research activities can be explained as follow:

i. Selecting of significance indicators for TPM and LM implementation according to previous research (based on literature review).

ii. Determining MP indicators that will be measured as the impact of the implementation of TPM and LM programs.

iii. Formulating the models (CFA models and Structural Model) using SEM tools.

iv. Generating a questionnaire to measure variables, conducting pilot study ( $1^{\text {st }}$ data collecting $\left.n=30\right)$.

v. Performing validity and reliability test.

vi. Revising the questionnaires based on validity and reliability test.

vii. Determine research object and conducting $2^{\text {nd }}$ data collecting $(n=250)$

viii. Data processing using Smart-PLS software.

ix. Analysing and comparing the results through SEM standard values.

x. Conclusion, documentation and publication.

\subsection{Research Philosophy}

Many researchers have conducted researches on the implementation of TPM and LM, as well as their relationship with MP. However, most of them, if not all looked at their implementation as a separate tool. With this in mind, there is a 
slant to provide a ground to study their integration in manufacturing industries. Without having a TPM as complementary, the LM initiative cannot be accomplished [3], [12]. To achieve World Class Manufacturing companies, integration of TPM and LM is a must. A comprehensive integration between TPM and LM initiatives will boosting MP.

Unfortunately, TPM implementation is not an easy task by any means, and the number of companies successfully implemented this program is considered relatively small Ahuja. There were pillars, barriers and enablers that influence the success or failure of TPM implementation. Regarding the pillars, barriers and enablers of TPM implementation, researchers have different opinions. [14] mentioned only 2 pillars of TPM that were considered important while [21] considered 4 pillars. [22] mentioned only 6 pillars are significant. Whereas according to [3], [4] and [23] the entire edifice of TPM is built and stands on 8 (eight) pillars.

Many researchers namely [3], [24], and [25] have identified some barriers to implement TPM which could be summarized as follows: lack of management commitment and support, lack of employee involvement, lack of training and education, lack of organizational communication, lack of a clear understanding TPM, lack of supports system, and the last and the most is resistance to change (individual and organizational).

For LM, [26] show that processes and equipment, planning and control, supplier relationship, human resources and customer relation were strongly significant to LM. [10] shows empirically identifying 10 underlying components in 48 items that represent LM. [27] revealed that using the AHP analysis shows that TPM, Kaizen and 5S are the most influential LM practices. [8] gives the various lean principles/ methods as follows: Cellular Manufacturing, Just in time, Continuous Improvement, Production Smoothing, Standardization of Work, and TPM. These principles from [8] will be used as LM variables for this research.

To measure the impact of TPM and LM practices to MP, many authors have different criteria. The TPM practices have positive and significant relationship with manufacturing performance and significantly improve cost effectiveness, product quality, on-time delivery and volume flexibility [28]. The OEE measure is treated as an important indicator of the success of TPM program [9], [29]. [30] found that the most crucial components to leanness are defects, cost, lead time, and value. [13] [14] found that LM techniques, practices, positively and significantly affect quality, cost, flexibility and delivery.

These condition raise a question to be answered. The question is how many pillars and what pillars that builds successful TPM? What barriers and enablers that influence to successful TPM and LM? How many principles for successful LM? What is the optimum model which is represent the relationship between TPM, LM and MP? To answer this question an approach needs to be established.

First of all is to select from the literature indicators for TPM, LM and MP. The next step is generating questionnaires, conducting pilot study and following with validity and reliability test. Confirmatory Factors Analysis (CFA) and measurement model (SEM) are then used to draw the relationship among variables. The data obtained through questionnaires will be processed and analyzed using Structural Equation Modeling method with SmartPLS as programming tools. The optimum models (CFA and SEM) will be determined from this process. It is expected that the result obtained can be beneficial to bring out the knowledge about manufacturing performance optimization strategy through TPM and LM implementation.

\section{Research Hypotheses and Expected Results}

\subsection{Proposed Model}

The model proposed for investigating the relationship of TPM, LM and MP was provided on Figure. 2

\subsection{Research Hypotheses}

Four (4) hypotheses (H1 to H4) will be tested. H1: TPM practices has significantly impact to Lean Manufacturing (LM); H2: TPM practices has significantly impact to Manufacturing Performance (MP); H3: LM practices has significantly impact to Manufacturing Performance (MP). H4: TPM and LM practices have significantly impact to Manufacturing Performance (MP).

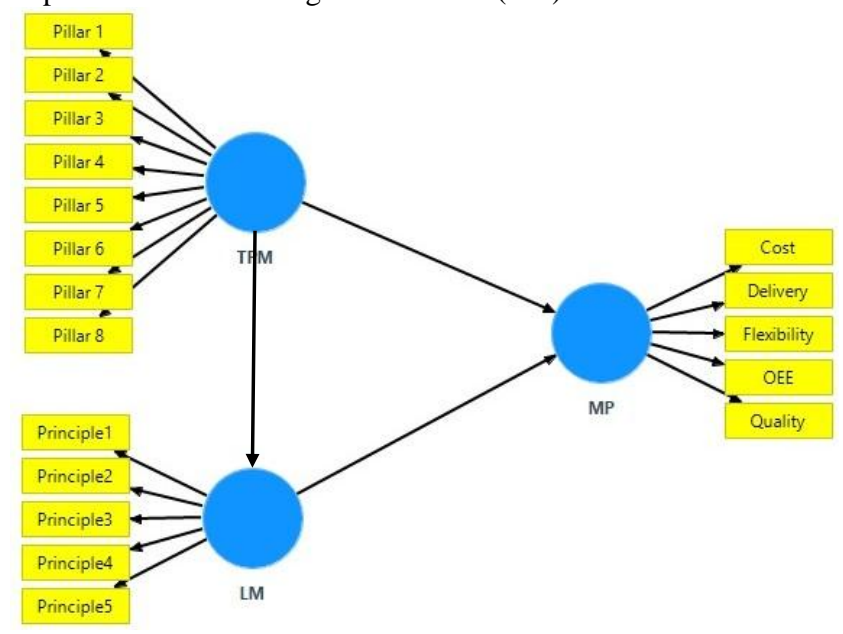

Fig.2: Proposed Model

\subsection{Expected Results}

In summary, the expected outcomes of this research are:

1.Providing updated barriers and enablers factors in implementing TPM and LM in Manufacturing Industries.

2. Provided reliable CFA (measurement) models for TPM, LM and MP.

3. Proposing reference (structural) model of the relationship between TPM, LM and MP for Indonesian manufacturing industries.

\section{Acknowledgment}

Special thanks to my supervisor Erry Yulian Triblas Adesta for supervising me and who have helped me to get Grants from FRGS (Fundamental Research Grants Scheme) UIAM with Grant number: FRGS/1/2015/TK03/UIAM/01/1 to attend the conference and to publish my paper in the Scopus indexed journal (IJET- International Journal of Engineering and Technology- UAE).

\section{References}

[1] Bappenas, "Sectoral Development Performance Evaluation," Directorate of The Ministry of BPN, Jakarta, 2017.

[2] Kemenperin, " (http://kemenperin.go.id/artikel/5787/ManufakturSumbang-40-PDB,"

(http://kemenperin.go.id/artikel/5787/Manufaktur-Sumbang-40-PDB, Jakarta, 2017.

[3] Ahuja, IPS., JS Khamba, "Total Productive Maintenance: Literature review and directions," International Journal of Quality and Reliability Management, vol. 25, no. 7, pp. 709-756, 2008.

[4] Nakajima, S., Introduction to TPM, Cambridge: Productivity Press, 1988.

[5] Teeravaraprug, J., K. Kitiwanwong, N. Saetong, et.al, "Relationship model and supporting activities of JIT, TQM and TPM," Journal of Science and Technology, vol. 33, no. 1, pp. 101-106, 2011.

[6] Dutta, S., AK Dutta, "A Review on the experimental study of," 
International Journal of Engineering Trends and Technology (IJETT), vol. 36, no. 5, 2016.

[7] Womack, JP., DT Jones, D.1 Ross, The Machine that Change the World, New York: Rawson Associates Scribner, Simon and Schuster Inc., 1990.

[8] Mishra, Y., M. Kachawaha, K. Jain, "A Review on Lean Manufacturing and Its Implementation," in Emerging Trends in Engineering and Management, Jaipur, 2016.

[9] Anvari, A., Y. Ismail, S.M. Hossen, "A Study on TQM and Lean Manufacturing Through Lean Thinking Approach," World Applied Sciences Journal, 2011.

[10] Shah, R., PT. Ward, "Defining and Developing Measures of Lean Production," Journal of Operation Management, Elsevier, vol. 25, pp. 785-805, 2007.

[11] Upadhiye, N., SG Desmukh, S. Garg, "Lean Manufacturing Systems Barriers," International Journal on Lean Enterprise Research, vol. 2 , no. 1, pp. 46-65, 2016.

[12] Bakrie, AH., A. Rahman, NM Yusof, et.al, "Boosting Lean Manufacturing via TPM," Social and Behavioural Sciences, Procedia, vol. 65, pp. 485-491, 2012.

[13] Belekoukias, I., JAG Reyes, V. Kumar, "The Impact of Lean Methods and Tools on The Operational Performance of Manufacturing Organizations," International Journal of Production Research, vol. 52, pp. 5346-5366, 2014.

[14] Cua, KO., KE McKone, RG Schroeder, "Relationships between implementation of TQM, JIT and TPM and manufacturing performance," Journal of Operation Management, vol. 19, pp. 675694,2001

[15] Hashim, S., NF Habidin, J. Conding, et.al, "The Integrated Between Total Production Maintenance Practices And Kaizen Event Practices In Malaysian Automotive Industry," International Journal of Engineering Research and Application, vol. 3, no. 11, pp. 62-67, 2012.

[16] Prabowo, HA., Farida, R Indar, "Improve the Work Effectiveness with Overall Equipment Effectiveness (Oee) as the Basis for Optimizing Production," PASTI, vol. 9, no. 3, 2010.

[17] Triwardani, DH., A. Rahman, CFM Tantrika, "ANALYSIS OF OVERALL EQUIPMENT EFFECTIVENESS TO REDUCE SIX BIG," Jurnal Rekayasa, 2013.

[18] Kuncoro, EGB., DSE Atmaja, "ANALISIS PERAWATAN DAN EFEKTIVITAS MESIN CONTINUOUS," in Seminar Nasional Inovasi dan Aplikasi Teknologi di Industri, ITN Malang, 2018.

[19] Hazmi, FW., PD Karningsih, H Supriyanto, "Penerapan Lean Manufacturing Untuk Proses," Jurnal Teknik ITS, vol. 1, no. 1, pp. 135-140, 2012.

[20] Khannan, MSA., Haryono, "Analisis Penerapan Lean Manufacturing untuk," Rekayasa Sistem Industri, vol. 4, no. 1, pp. 47-54, 2015.

[21] Adesta, EYT., HA PRABOWO, "Evaluating 8 pillars of Total Productive Maintenance (TPM) implementation and their contribution to manufacturing performance," in IOP Conference Series: Materials Science and Engineering, Kuala Lumpur, 2018.

[22] Prabowo, HA., Y. Bobby, Farida, "The Evaluation of Eight Pillars Total Productive Maintenance (Tpm) Implementation and Their Impact on Overall Equipment Effectiveness (Oee) and Waste," SINERGI, vol. 22, no. 1, pp. 13-18, 2018.

[23] Pandey, DS., N Raut, "Implementing TPM by doing Root Cause Analysis of Downtime Losses," International Journal of Advanced Research in Science, Engineering and Technology, vol. 3, no. 2, pp. 1399-1405, 2016.

[24] Poduval, PS., J. RajVP, VR Pramod, "Total Productive Maintenance And Role Of Interpretive Structural Modeling And Structural Equation Modeling In Analyzing Barriers," International Journal of Quality \& Reliability Management, vol. 4, no. 9, pp. 302-315, 2015.

[25] Kumar, A., RK Singh, TA Khan, "Development of Framework for Analyzing the Barriers in Total," International Journal of Advance Research and Innovation, vol. 4, no. 4, pp. 742-748, 2016.

[26] Zahraee, SM., A. Hashemi, AA Abdi, et.al, "Lean Manufacturing Implementation Through Value Stream Mapping: A," Jurnal Teknologi, vol. 68, no. 3, pp. 119-124, 2014.

[27] Thanki, S., Kannan Govindan, Jittesh Takkar, "An investigation on lean-green implementation practices in Indian SMEs using analytical hierarchy process (AHP) approach," Journal of Cleaner Production, Elsevier, vol. 135, no. 1, pp. 284-298, 2016.

[28] Wickramasinghe, GLD., A. Perera, "Effect of total productive maintenance practices on manufacturing performance: Investigation of textile and apparel manufacturing firms"," Journal of Manufacturing Technology Management, vol. 27, no. 5, pp. 713-729, 2016.

[29] Gupta, P., S. Vardhan, "Optimizing OEE, productivity and production cost for improving sales volume in an automobile industry through TPM: a case study," International Journal of Production Research, vol. 54, no. 10, pp. 2976-2988, 2016.

[30] Anvari, A., N. Zulkifli, RM. Yusuff, "A dynamic modeling to measure lean performance within lean attributes," International journal of Advanced Manufacturing Technology, no. DOI 10.1007/s00170-012-4356-0, 2013. 